\title{
Glass ceiling in the accounting profession: Evidence in Brazilian companies
}

\author{
Glass Ceiling en la profesión contable: la evidencia \\ en las empresas brasileñas \\ Júlio César da Silva*, Cristian Baú Dal Magro, \\ Marcello Christiano Gorla, Marcia Zanievicz da Silva
}

Universidade Regional de Blumenau - FURB - Brasil

Received 30 november 2015; accepted 6 april 2016

Available online 16 march 2018

\begin{abstract}
Although there are several studies on gender differences in occupations, few studies address the accounting profession, in particular those related to the occurrence of the glass ceiling effect, a barrier that hinders and even prevents the career growth of women. In this context, the study aims to verify the influence of glass ceiling in relation to gender inequality in the accounting profession. The investigated population consists of professionals in accounting from companies located in southern Brazil, and the sample consists of 34,886 observations. The results indicate that the top positions in the Accounting Auditor and Accountant professions are held predominantly by men. A difference in pay was observed, as men receive higher remunerations than women in similar functions. There is a predominance of accounting male professionals in large companies and female professionals in small and medium-sized businesses, and men tend to stay longer in positions of the accounting profession in the same company. It is concluded that the occurrence of glass ceiling influences on the increased difficulty of access for women in key positions in the accounting profession, confirming the gender inequality observed in studies regarding other professional activities.

\footnotetext{
* Corresponding author.

E-mail address: profjuliosilva72@gmail.com (J.C. Da Silva)

Peer review under the responsibility of Universidad Nacional Autónoma de México.
} 
JEL Classification: J16, J82, M4

Keywords: Glass Ceiling; Gender inequality; Accounting profession; Accounting auditor; Brazilian companies.

\section{Resumen}

Aunque existen varios estudios sobre las diferencias de género en las ocupaciones, pocos estudios abordan la profesión contable, en particular los relacionados con la aparición de Glass Ceiling, las barreras que dificultan e incluso impiden el crecimiento de la carrera de las mujeres. En este contexto, el estudio tiene como objetivo verificar la influencia del Glass Ceiling en relación con la desigualdad de género en la profesión contable. La población investigada está formado por profesionales en contabilidad de las empresas ubicadas en el sur de Brasil, y la muestra se compone de 34.886 observaciones. Los resultados indican que las primeras posiciones en Auditor Contable y Contador Contable se llevan a cabo principalmente por los hombres. Fue observado diferencia salarial, los hombres reciben una remuneración mayor que las mujeres en funciones similares. Hay un predominio de profesionales masculinos en la contabilidad las grandes empresas y mujeres profesionales en pequeñas y medianas empresas, y los hombres tienden a permanecer más tiempo en posiciones de la profesión contable en la misma empresa. Se concluye que la presencia de las influencias de Glass Ceiling en el aumento de la dificultad de acceso de las mujeres en posiciones clave en la profesión contable, lo que confirma la desigualdad de género observada en estudios en otras actividades profesionales.

Códigos JEL: J16, J82, M4

Palabras clave: Glass Ceiling; Desigualdad de género; Profesión contable; Auditor contable; Las empresas brasileñas.

\section{Introduction}

Although the participation of women in society is increasing, there is asymmetry in gender relations in the labor market, especially in relation to the wage gap in similar positions and to the access for women in certain hierarchical positions (Cambota and Pontes, 2007; Cavazotte, Oliveira and Miranda, 2010). Despite the evolution of women in the labor market, which has been causing deep cultural changes, the business environment is still defined by male standards (Rothwell, 1985; Muzio and Tomlinson, 2012).

In recent decades, there has been growing interest in making visible the factors that could hinder the development of women in the accounting profession. However, research on the subject has been restricted to recruitment, retention, progression, and the turnover rate of women (Pillsbury, Capozzoli and Ciampa, 1989; Ciancanelli, Gallhofer, Humphrey and Kirham, 1990; Roberts and Coutts, 1992).

Despite the above, studies have proposed investigating the existing barriers for women in the professional field. Lehman (1992) noted that practices restricting the access of women to the accounting profession have persisted since the early 1900s, and literature has not been able to articulate the nature of the discriminatory practices. Barcelona, Lelievre and Lelievre (1975), in a survey of female accountants, comment that at that time there were slow incursions into discrimination in accounting supervision levels. Already in the findings of Fischer (1987) 
women represented between $35 \%$ and $50 \%$ of all new employees in Auditing; however, promotions, responsibilities, and salaries were allocated disproportionately, and few women ended up occupying the partner position in an audit firm.

In 1983, the eight major audit firms in the world had about 6,000 partners, with only 62 women (Gould, 1983). In 1986, the Census Bureau report indicated that women accounted for $45 \%$ of all accountants and auditors. Although there have been advances, the Census Bureau shows differences in male and female earnings, with women still earning on average $69 \%$ less (Pear, 1987). More recently, Casa Nova (2012) notes that gender inequality will be overcome over time, because education is spreading among women, who will naturally take up new opportunities.

One of the most popular approaches on inequality in relation to gender in the labor market was conceived as the glass ceiling effect. This effect deals with the difficulty in professional growth and with the creation of invisible obstacles for the promotion of women and minorities to higher levels of the organizational hierarchy (Morrison and Glinow, 1990; Steil, 1997).

Despite the existence of national and international research exploring the glass ceiling effect, little is known about its occurrence in the accounting profession. For this reason, the following research question was defined: What is the influence of the glass ceiling effect in relation to gender inequality in the accounting profession? To answer this question, the study aims to verify the influence of the glass ceiling effect in relation to gender inequality in the accounting profession by conducting a survey in southern Brazil.

For the importance of studies that deal with the accounting profession and critical reviews, Cooper (2001) provided proper attention to gender issues. Furthermore, particularly regarding glass ceiling in the accounting profession — although being the object of study in international research, as indicated by Richardson (1996), Barker and Monks (1998), Twomey, Linehan and Walsh (2002), Haynes (2008), Abidin, Rashid and Jusoff (2009) and Bruce-Twum (2013), in the context under study, the effect in question and at this point in time-, such discussion is necessary and indicates relevant research.

Additionally, by addressing gender inequality, the study seeks to contribute in the pursuit actions aiming its reduction, confirming the positioning of Hoffmann (2004). Another contribution is the inclusion of arguments regarding the existence of restrictions and discrimination against women, and the findings seek to ratify the need for the appreciation of women in accounting. Such results can contribute to the promotion of such discussion in the academy, and to awareness for the need to minimize professional barriers, favoring the retention of women in accounting and valuing those with superior skills.

The choice of the southern region of Brazil is justified by the fairness of the economic context. According to the Brazilian Institute of Geography and Statistics (IBGE for its acronym in Portuguese) (2014), the monthly income per capita of the resident population in 2014 among the southern states is similar. The ranking of gross domestic product (GDP) of the Brazilian states is also similar to that of the states of Rio Grande do Sul in the fourth position, Paraná in the fifth, and Santa Catarina in the sixth position of the national GDP. Thus, it is justified due to the possibility of similar professional opportunities for women residing in these states.

On the contrary, the inclusion of other states could generate bias in the findings, since there is an identified economic disproportionality. 


\section{Gender inequality and Glass Ceiling}

Glass ceiling is a concept introduced in the United States in the 1980s, to describe a transparent and subtle barrier that is able to make the rise of women to the highest levels of the organizational hierarchy impossible. Thus, women are prevented from advancing, based on gender and not by the inability of occupying higher functions (Powell and Butterfield, 1994; Ohlott, Ruderman and Mccauley, 1994).

The Federal Glass Ceiling Commission, in the USA (1995), defines it as "... artificial barriers to the development of women and minorities," referring to these barriers as follows: Discrimination - a deep line of demarcation between those who thrive and were left behind - is an invisible barrier, still insurmountable, that keeps minorities and women from climbing the top rungs of the corporate ladder, regardless of their qualifications.

For Cotter, Hermsen, Ovadia and Vanneman (2001) Each of the employment characteristics can be fruitfully investigated as exhibiting glass ceiling effects; however, this study addressed rank, occupation, and remuneration.

In terms of studies that link glass ceiling to occupations and, in particular, the accounting profession, there are various approaches. Martin (1990) notes that women are segregated in occupational terms, unfairly assessed, and paid less than men.

Ohlott et al. (1994) suggest a discriminatory impact, which points to a lower propensity of men to delegate challenging tasks to women, showing evidence on the glass ceiling effect.

Particularly in accounting, Richardson (1996), in a study of UK professionals, found that male and female accountants have different career paths with higher compensation standards for men. Social expectations attributed to men refer to a continuous professional path, with linear and rapid career progression, whereas women are expected to have children and give them priority at the expense of their career.

Barker and Monks (1998) compared the career development of men and women accountants in Ireland, focusing on barriers to career development. They indicate that women face obstacles that do not occur with men. Moreover, career development is more common among women who forego family life.

According to Acs, Bardasi, Estrin and Svejnar (2011), the barriers that women face are the result of educational experiences, family roles, social roles, and a lack of networking.

Twomey et al. (2002) investigated the career development of young accountants of Generation X in Ireland, analyzing whether the new generation experienced the glass ceiling effect during their accounting career. The results show that Generation $\mathrm{X}$ female accountants also face obstacles and from their point of view male domination in the accounting profession tends to last.

Abidin et al. (2009), based on a study conducted in Malaysia, argue that organizations are not built to accommodate the values of women. This is because women entered the business world late and have a very narrow range of occupations. Furthermore, many workplaces did not change their policies to allow the balance between work and family responsibilities.

The study by Cooper (2010) reflects the prevailing attitude of men towards the admission of women in professional accountancy bodies in the years of professional training in Australia. The study showed that Australian women seeking a career in accounting and participating in professional accountancy bodies in the late nineteenth century and early twentieth century faced various forms of discrimination. 
The study by Bruce-Twum (2013) sought to discover whether female accountants in Ghana were affected by the glass ceiling effect. The findings suggest that there was an increase in the number of women admitted as part of the Institute of Chartered Accountants of Ghana; however, no woman has been selected to perform in high hierarchical level functions.

One the factors that seem to affect business performance with regard to women is education - those with higher education perform better-, and the difference with respect to men decreases when women with university careers are the subject of study (Runyan, Huddleston and Swinney, 2006).

Madero Gómez (2010) investigated the importance of 27 factors of human resources in the working career of individuals. Among the main results, the education level, communication skills, and family support are highlighted as reducing gender inequality factors in the careers of women.

The studies by Dwyer, Johnston and Miller (1996) and Steil (1997) indicate that in the twentieth century, men still had a greater tendency to cover managerial functions and decisionmaking positions, a fact that reveals the presence of glass ceiling and distorts the recurring discourse of gender equality, which is often explained in the Social Report of organizations.

\section{Studies on gender inequality in various professions}

Contemporary studies in other professional fields have also shown the existence of gender inequality and invisible barriers that restrict the access of women to career advancement, professional development, and wage equality. Powell, Bagilhole and Dainty (2009) comment that the engineering field professions have always been characteristic of a male occupation. Furthermore, they report that strategies for reducing gender inequality to increase the number of women in engineering professions were developed, but the success of said strategies were considered to be limited.

Michelson (2009) suggests the existence of gender inequality in the legal profession of private law in the labor market of China. The author shows that, although there is a quantitative expansion in job opportunities for female lawyers, their careers have been qualitatively, in terms of status and income, less valued compared to male professionals.

The study by Walsh (2012) examines the aspirations of career progress and the perceptions of opportunities for female lawyers in Wales and England. The study finds that strong aspirations in career progress (partners in law firms) does not necessarily prevent a balanced lifestyle, integrating work and personal life. Moreover, regarding opportunities, even women with strong aspirations realize that their promotion has been restricted, proving the existence of barriers for career progress.

England (2010) offers contemporary arguments to explain the little progress in the valuation and professional equality of women. The author highlights that women showed strong incentive to enter the men dominated professions, whereas on the other hand, men have little incentive to take on women dominated functions (nursing, physiotherapy, social work, among others). In this sense, most people follow the typical gender paths, making inequality persist in many professions. For women, inequality persists in top management jobs, management jobs, and jobs that require direct contact with clients. On the other hand, men have low rise in nursing and educational activities, as well as in the social and health areas. 
The arguments presented by England (2010), that women have occupied health professions was in part challenged by Adams (2010) by considering status factors and remuneration, suggesting that in professional areas dominated by women there is also incidence of gender inequality: men are still predominant in the functions of higher status and remuneration, such as medicine and dentistry, while women hold support functions such as nursing.

Crompton and Lyonette (2011) report that in Britain the medical profession is internally segregated by gender, where usually women hold lower clinical specialties. In general, they suggested that there is sexual discrimination of doctors and accountants with high qualification, and the factor underlying the trajectory of different careers related to gender remains responsible for housework and caring for the family which, in a nutshell, is practiced predominantly by women.

\section{Gender inequality in the accounting profession}

Historically, gender conflicts have restricted women from taking the identity of accountants, therefore, the top ranks of the accounting profession have been reserved for men (Lehman, 1992). Konstans and Ferris (1981) have mentioned that in audit, the turnover rate of women and men during the first year of work is not very different. However, in the third year the turnover rate doubles for women. Wescott and Seiler (1986) suggest that women resign due to dissatisfaction and not for personal reasons such as marriage, family and/or children.

Traditionally, leadership positions in organizations in the United States and other parts of the world are occupied mainly by men (Stelter, 2002). Even with the increasing number of women in the labor market and in management positions, their access to leadership positions remains limited (Eagly, Johannesen-Schmidt and Van Engen, 2003; Oakley, 2000; Ridgeway, 2001; Stelter, 2002) indicating the existence of barriers that prevent the professional advancement of women.

Oakley (2000) argues that there are three categories that explain the rise of women barriers: (1) corporate practices, such as recruitment, retention, and promotion; (2) behavioral and cultural causes, such as stereotypes and preferred leadership style; and (3) structural and cultural explanations rooted in feminist theory. Therefore, this study sought to focus on the business practices of recruitment, retention, and promotion of women in the accounting profession. Meyerson and Fletcher (2000) note that a woman could miss a promotion to a male colleague with less experience only because of gender discrimination.

Historically, the inclusion of women in the labor market is marked by progress and delays. On the one hand, there was an increase in female participation in the labor market, with access to careers, professions, and prestigious positions; on the other hand, high unemployment of women, poor conditions for the performance of the work, and female work predominantly in precarious and informal activities (Bruschini, 2007).

Kelan (2008) reveals three distinct ways in which gender is addressed. First, the awareness discourse seeks to reiterate the stereotype of gender through the representation of women. Second, in the individualization speech, gender discriminatory elements lost their importance. Finally, women are considered as ideal workers for the future. This indicates that there is little room for speeches that continue with the inequality awareness experienced by women in relation to men supporting the rhetoric for a post-feminism climate. 
Dwyer and Roberts (2004) analyzed contemporary social relations on gender in the public accounting profession in the United States. The results showed that, due to the inability of women to challenge the norms of domesticity, the equal participation of women in the profession cannot be expected.

Madero Gómez (2010) investigated the importance of 27 factors of human resources in the working career of individuals. Among the main results, the education level, communication skills, and family support are highlighted as reducing gender inequality factors in the careers of women.

Crompton and Lyonette (2011) also report in their study that, in Britain, women are restricted from taking high ranking positions in the career of accounting.

Lupu (2012) explored the mechanisms that stimulate the infrequency of women in top positions in accounting firms in France. The results showed that the career model characterized by ascendancy and constant mobility does not fit for most women, especially those with children. On the other hand, there are several alternative ways that women can pursue to continue balancing their professional and family aspirations: part-time work, narrow specialization, support work, and leaving early.

In a study conducted in Germany, Bach (2014) showed that gender inequality is much deeper than simple wage comparison. Using the income tax returns and considering wages, income per capita, and real estate, the study found that German women have obtained significantly lower income than men.

Brighenti, Jacomossi and Silva (2015) investigated gender inequality in the performance of accountants and auditors in the labor market of the State of Santa Catarina, Brazil. They concluded that even with an average range of education equal to that of men, the average pay for women is lower, suggesting gender inequality in the accounting labor market. Additionally, they verified if age, length of employment, education, and size of the company could justify the differences in pay between genders; however, these were similar for men and women, showing evidence of gender inequality.

Cisnero (2015) examined the differences in the background of new businesses started by men and women in Mexico City. The factors included in the analysis were professional experience, educational level, history of family entrepreneurs, age, gender, initial capital with which the company was formed, planning level, among others. The results indicate that there is no significant difference in the performance of new businesses, but there were differences in the amount of initial capital and income levels reported by men and women. This result proves the existence of inequality in third party capital availability for women starting new undertakings.

For Cisneros (2015) there was a sharp increase in female entrepreneurship throughout the world, and although higher in developed economies, it was also significant in Latin America. Particularly, cases of gender inequality in Latin America are no different from the rest of the world. Women have been taking a higher position in economics and business, but have not yet equaled men (World Bank, 2010).

Recently, there have been major policy initiatives in an effort to develop standards and work cultures in favor of reconciling professional with personal activities, a factor that can contribute to a reduction in gender inequality in professions (Muzio and Tomlinson, 2012). However, the literature refers to the inference that there is still much work to be done for the greater professional equality between men and women, both in the accounting profession and in other professional activities. 
Regulation and the differences between the accounting profession and Auditing

In the accounting profession, there are diverse opportunities and fields of activity. Da Silva et al. (2011) explains that through their work and judgment, the accountant (accountant or accounting technician) can perform various functions: register, quantify, design, analyze, evaluate, direct, and produce other elements, on which the economic, administrative and financial institutions depend, especially in deciding whether to keep or redirect actions as well as in the business direction and management of organizations.

It should be noted that the CFC Resolution No. 560 of October 28, 1983, provides the respective functions of the accounting profession, among which Auditing is included. Thus, the duties of an accounting officer are listed as: analyst, advisor, assistant, auditor (internal or external), consultant advisor, revenue controller, controller, educator, writer or technical writer, accounting or tax bookkeeping, subordinate executor, tax auditor, organizing legislator, expert, researcher, planner, teacher or lecturer, editor, and reviewer.

However, Ricardino and Carvalho (2004) reported the existence of a gap of nearly two hundred years separating the formalization of the use of double entry bookkeeping in the Portuguese Royal Treasury, through the Decree of June 28, 1808, and the introduction of the mandatory use of Independent Audit, on June 14, 1965. In both cases, they were regulated through legal documents. Lopes (2002) notes that the base on legal structures has made the model more focused on civil law, that is, accounting generally regulated directly and legally by the central government.

In this context, the auditing activity emerged in Brazil almost a century ago, but because of the legalistic characteristics of the country, its practice was regulated only from 1965. With regard to the scientific production, accounting professionals and academics, publications on this topic emerged approximately in 1928. As a subject, Auditing, initially called Review \& Forensic Accounting, was included officially in the curricula of the Higher Courses in Accounting from 1945 onward.

This was done in order to differentiate Auditing, - an area of the accountant, or of accounting - which is the profession itself. According to Attie (2009) auditing "is a dedicated accounting expertise to test the efficiency and effectiveness of asset control deployed for the purpose of expressing an opinion on certain data". For Franco and Marra (2001) auditing includes:

“...examination of documents, books and records, inspections and obtaining information and confirmations, internal and external, related to the control of assets, in order to measure the accuracy of these records and their financial statements resulting from them".

Additionally, it is important to endorse how regulations of accounting occur, especially auditing, in Brazil and in the world. The United Nations Conference on Trade and Development (UNCTAD) is a body linked to the United Nations (UN), which has a group of experts in international accounting standards called the Intergovernmental Group of Experts on International Standards of Accounting and Reporting (ISAR). According to Aggestam (1999), the ISAR is comprised of governmental and non-governmental organizations, and is the only UN intergovernmental body aimed at promoting the harmonization of accounting and auditing practices. 
Although thoroughly defining the content that should be included in the curricula of the accounting professional training courses, the ISAR states that its determinations represent only a guide to be followed by the HEIs, which are responsible for establishing subjects to be taught and the workload of each, observing the peculiarities of each country, such as: the constant changes in the economic scenario, cultural differences, and technological advances.

However, some facts have led to more comprehensive regulatory changes in Auditing. According to Niyama et al. (2011) the professional responsibilities of auditors were expanded from corporate scandals, which led to modifications of the self-profession regulatory process in the US market, as well as the institution of the PCAOB.

Large audit firms argue that they support efforts to standardize the accounting and auditing standards worldwide and that a "new business model" should be developed for the provision of information with better quality and timeliness, but that auditors are not and cannot be the last instance of insurers for financial and capital markets, and that there is a difference in expectations between what investors want from an audit and the audit carrying capacity.

Finally, as the analysis of PWC; KPMG; GT; BDO; DT; E \& Y (2006), it would be important to search for a convergence/harmonization of auditing standards, as it is being implemented in relation to international accounting standards. In this sense, the way would be through the International Standards of Auditing (ISAs) developed by IFAC.

Particularly in Brazil, in late 2009, the Federal Accounting Council (CFC) approved a package with the new auditing standards for the audit of financial statements in convergence with the parameters of the standards developed by the IFAC, placing the Brazilian market in line with this harmonization movement of audit practices.

In this sense, auditors in the sample of this work have been working on converging parameters for other countries that follow the International Standards of Auditing (ISAs) developed by IFAC, which allows a possible comparison with less distortion.

\section{Research Methodology}

Data were collected in the 2013 Annual Social Information Report (RAIS for its acronym in Portuguese), available on the website of the Ministry of Labor and Employment. The attendees were professionals in accounting, with a formal contract of employment in companies located in the three southern states of the country: Rio Grande do Sul, Santa Catarina, and Paraná. The occupations were selected according to the Brazilian Code of Occupation (CBO), encoded as 252210 - Accountant, CBO 252205 - Auditor, and CBO 413110 - Accounting Assistant, with a total population of 81,756 observations.

For sample extraction, first information on the accounting area was selected. Subsequently, professionals who did not have a higher education were excluded, so that the parameters were the same in all positions of the accounting hierarchy. The sample was comprised of 34,886 observations.

The extracted information gave rise to the following research variables: gender, position, education, age, compensation, company size, time in the position, and state of the southern region. In the application of statistical techniques, the variables were categorized as shown in Table 1. 

http://dx.doi.org/10.22201/fca.24488410e.2018.928

Table 1

Categorization of research variables using 2013 base year data.

\begin{tabular}{|c|c|c|c|}
\hline Variable & Nonmetric Categorization & $\begin{array}{l}\text { Metric } \\
\text { Categorization }\end{array}$ & Theoretical Basis \\
\hline Gender & $\begin{array}{l}\text { Male } \\
\text { Female }\end{array}$ & $\begin{array}{l}01 \\
02\end{array}$ & $\begin{array}{l}\text { Duleep and Sanders (1992); Lehman } \\
\text { (1992); Roberts and Coutts (1992); Powell } \\
\text { e Butterfield (1994); Ohlott et al., (1994); } \\
\text { Frankforter (1996); Steil (1997); Fernandez } \\
\text { (1998); Twomey et al., (2002); Dwyer } \\
\text { and Roberts (2004); Casa Nova (2012); } \\
\text { Brighenti et al., (2015); Cisnero (2015). }\end{array}$ \\
\hline Position & $\begin{array}{l}\text { Accounting Auditor } \\
\text { Accountant } \\
\text { Accounting Assistant }\end{array}$ & $\begin{array}{l}01 \\
02 \\
03\end{array}$ & $\begin{array}{l}\text { Barcelona et al., (1975); Powell and } \\
\text { Butterfield (1994); Ohlott et al., (1994); } \\
\text { Frankforter (1996); Fernandez (1998); } \\
\text { Barker and Monks (1998); Meyerson and } \\
\text { Fletcher (2000); Twomey et al., (2002); } \\
\text { Cooper (2010); Lupo (2012); Bruce-Twum } \\
\text { (2013); Abidin } \text { et al., (2009). }\end{array}$ \\
\hline Education & $\begin{array}{l}\text { College Degree } \\
\text { Master Degree } \\
\text { Doctorate }\end{array}$ & $\begin{array}{l}01 \\
02 \\
03\end{array}$ & $\begin{array}{l}\text { Meyerson and Fletcher (2000); Cooper } \\
\text { (2001); Runyan et al., (2006); Madero } \\
\text { Gómez (2010); Brighenti et al., (2015); } \\
\text { Cisnero (2015). }\end{array}$ \\
\hline Age & $\begin{array}{l}16-20 \\
21-25 \\
26-30 \\
31-40 \\
41-50 \\
>50\end{array}$ & $\begin{array}{l}01 \\
02 \\
03 \\
04 \\
05 \\
06\end{array}$ & $\begin{array}{l}\text { Barcelona et al., (1975); Crompton and } \\
\text { Sanderson (1990); Richardson (1996); } \\
\text { Cambota and Pontes (2007); Cisnero (2015) }\end{array}$ \\
\hline Remuneration & $\begin{array}{l}<\mathrm{R} \$ 2,000.00 \\
\mathrm{R} \$ 2,000.00 \text { to } \mathrm{R} \$ 5,000.00 \\
\mathrm{R} \$ 5,000.00 \text { to } \mathrm{R} \$ 8,000.00 \\
>\mathrm{R} \$ 8,000.00\end{array}$ & $\begin{array}{l}01 \\
02 \\
03 \\
04\end{array}$ & $\begin{array}{l}\text { Pear (1987); Duleep and Sanders (1992); } \\
\text { Cooper (2010); Bach (2014); Brighenti et } \\
\text { al., (2015). }\end{array}$ \\
\hline Company Size & $\begin{array}{l}\text { Small } \\
\text { Medium } \\
\text { Large }\end{array}$ & $\begin{array}{l}01 \\
02 \\
03\end{array}$ & Gould (1983); Brighenti et al., (2015). \\
\hline Time in position & $\begin{array}{l}<1 \text { year } \\
1 \text { to } 3 \text { years } \\
3 \text { to } 5 \text { years } \\
>5 \text { years }\end{array}$ & $\begin{array}{l}01 \\
02 \\
03 \\
04\end{array}$ & $\begin{array}{l}\text { Konstans and Ferris (1981); Wescott and } \\
\text { Seiler (1986); Richardson (1996); Abidin et } \\
\text { al., (2009); Lupu (2012); Brighenti et al., } \\
\text { (2015); Cisnero (2015). }\end{array}$ \\
\hline $\begin{array}{l}\text { State of the Southern } \\
\text { Region }\end{array}$ & $\begin{array}{l}\text { SC - Santa Catarina } \\
\text { RS - Rio Grande do Sul } \\
\text { PR - Paraná }\end{array}$ & $\begin{array}{l}01 \\
02 \\
03\end{array}$ & IBGE (2014). \\
\hline
\end{tabular}

Source: Research data (2013).

Initially, the data were analyzed through a bivariate analysis to verify the relation/association between the studied variables. In this case, the chi-square test was performed using the SPSS software applicable to the model variables used in the research, as shown in Table 1. The 
chi-square test can be used as an extension of the binomial test and compares the observed frequencies with those expected in each category.

Finally, multiple correspondence analyses were applied using the SPSS software, in order to identify the gender profile on the other variables. The procedure to make the correspondence analysis technique was through HOMALS (Analysis of Homogeneity).

\section{Analysis of Results}

The composition of the frequency of each variable can be observed in Table, which contains the composition of the sample distributed by gender for a total of 34,886 observations, divided into $44 \%$ for males and $56 \%$ for females. The table summarizes the data on the variables of position, education, age, compensation, company size, time in the position, and state of the southern region.

Regarding the distribution of positions by gender, the highlight is the Accountant position, which has the highest volume with 18,909 observations, with some proportional distribution between males and females. The educational level distribution, particularly of professionals with higher education, is due to the sample selection, which is why it is the educational level of the majority, with 34,553 observations. In the age distribution, it is observed that the majority of people fall within the range of 31 to 40 years of age, with 12,772 observations, and there is a predominance of females in this age group.

With regard to remuneration, the data show that in the salary range between $\mathrm{R} \$ 2,000.00$ and $\mathrm{R} \$ 5,000.00$ there is a higher ratio of women compared to men. Regarding the size of the companies, it is shown that large companies account for the largest amount, with gender distributed practically equitably between male and female.

As for time in the position, the largest volume of observations is in the group of over five years in office, with 10,322 observations; followed very closely by the group with less than a year, and by that of one to three years in office. Finally, location by state is shown, with the state of Paraná presenting the largest number, with 13,613 observations, and a small difference between the number of males and females. Regardless, the states of Rio Grande do Sul and Santa Catarina show similarity in the number of professionals working in accounting, with some predominance of females. 
Table 2

Descriptive statistics observed using 2013 base year data.

\begin{tabular}{|c|c|c|c|c|c|c|c|c|c|c|c|c|}
\hline Gender & \multicolumn{4}{|l|}{ Male } & \multicolumn{4}{|c|}{ Female } & \multicolumn{4}{|l|}{ Total } \\
\hline n. & \multicolumn{4}{|c|}{15,239} & \multicolumn{4}{|c|}{19,647} & \multicolumn{4}{|l|}{34,886} \\
\hline$\%$ & \multicolumn{4}{|c|}{$44 \%$} & \multicolumn{4}{|c|}{$56 \%$} & \multicolumn{4}{|l|}{$100 \%$} \\
\hline Position & \multicolumn{4}{|c|}{ Accounting Auditor } & \multicolumn{4}{|c|}{ Accountant } & \multicolumn{4}{|c|}{ Accounting Assistant } \\
\hline Gender & \multicolumn{2}{|l|}{ Male } & \multicolumn{2}{|c|}{ Female } & \multicolumn{2}{|l|}{ Male } & \multicolumn{2}{|c|}{ Female } & \multicolumn{2}{|l|}{ Male } & \multicolumn{2}{|c|}{ Female } \\
\hline n. & \multicolumn{2}{|l|}{2,346} & \multicolumn{2}{|c|}{1,490} & \multicolumn{2}{|l|}{9,471} & \multicolumn{2}{|l|}{9,438} & \multicolumn{2}{|l|}{3,422} & \multicolumn{2}{|l|}{8,719} \\
\hline$\%$ & \multicolumn{2}{|c|}{$61 \%$} & \multicolumn{2}{|l|}{$39 \%$} & \multicolumn{2}{|l|}{$50,1 \%$} & $49,9 \%$ & & $28 \%$ & & $72 \%$ & \\
\hline Education & Colle & e Degr & & & Maste & er Degree & & & Doctor & rate & & \\
\hline Gender & Male & & Femal & & Male & & Femal & & Male & & Fema & \\
\hline $\mathrm{n}$. & 15,07 & & 19,480 & & 138 & & 132 & & 28 & & 35 & \\
\hline$\%$ & $44 \%$ & & $56 \%$ & & $51 \%$ & & $49 \%$ & & $44 \%$ & & $56 \%$ & \\
\hline Age & $16-20$ & & $21-25$ & & $26-30$ & & $31-40$ & & $41-50$ & & $>50$ & \\
\hline Gender & Male & Female & Male & Female & Male & Female & Male & Femal & Male & Female & Male & Female \\
\hline $\mathrm{n}$. & 40 & 56 & 1,296 & 2,517 & 2,886 & 5,107 & 5,208 & 7,564 & 3,460 & 3,358 & 2,349 & 1,045 \\
\hline$\%$ & $42 \%$ & $58 \%$ & $34 \%$ & $66 \%$ & $36 \%$ & $64 \%$ & $41 \%$ & $59 \%$ & $51 \%$ & $49 \%$ & $69 \%$ & $31 \%$ \\
\hline Remuneration & $<\mathbf{R} \$$ & $2,000.00$ & & $\begin{array}{l}\text { R\$ 2,00 } \\
\mathbf{5 , 0 0 0 . 0 0}\end{array}$ & $.00-R$ & & $\begin{array}{l}\text { R\$ 5,0 } \\
8,000 .\end{array}$ & $\begin{array}{l}00.00- \\
00\end{array}$ & & $>\mathbf{R} \$ \mathbf{8 , 0}$ & 00.00 & \\
\hline Gender & Male & & emale & Male & & Female & Male & & emale & Male & & Female \\
\hline n. & 3,725 & &, 050 & 6,571 & & 8,763 & 2,521 & &, 771 & 2,422 & & 1,063 \\
\hline$\%$ & $32 \%$ & & $8 \%$ & $43 \%$ & & $57 \%$ & $59 \%$ & & $1 \%$ & $70 \%$ & & $30 \%$ \\
\hline Company Size & Small & & & & Mediu & $\mathrm{am}$ & & & Large & & & \\
\hline Gender & Male & & Femal & & Male & & Femal & & Male & & Fema & \\
\hline n. & 4,057 & & 6,718 & & 3,439 & & 5,099 & & 7,743 & & 7,830 & \\
\hline$\%$ & $38 \%$ & & $42 \%$ & & $41 \%$ & & $59 \%$ & & $49,7 \%$ & & $50,2 \%$ & \\
\hline $\begin{array}{l}\text { Time in } \\
\text { position }\end{array}$ & $<1$ ye & & 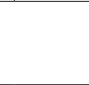 & 1-3 year & & & 3-5 ye & ars & & $>5$ year & & \\
\hline Gender & Male & & emale & Male & & Female & Male & & Female & Male & & Female \\
\hline $\mathrm{n}$. & 3,860 & & 917 & 3,874 & & 5,727 & 2,139 & &, 047 & 5,366 & & 4,956 \\
\hline$\%$ & $40 \%$ & & $0 \%$ & $40 \%$ & & $60 \%$ & $41 \%$ & & $9 \%$ & $52 \%$ & & $48 \%$ \\
\hline State & $\mathrm{SC}$ & & & & RS & & & & PR & & & \\
\hline Gender & Male & & Femal & & Male & & Femal & & Male & & Fema & \\
\hline n. & 4,511 & & 6,145 & & 4,157 & & 6,460 & & 6,571 & & 7,042 & \\
\hline$\%$ & $42 \%$ & & $58 \%$ & & $39 \%$ & & $61 \%$ & & $48 \%$ & & $52 \%$ & \\
\hline
\end{tabular}

Source: Research Data. 


\section{Analysis of association between variables}

The study aimed to verify the association between the variables that characterize the existence of glass ceiling in the accounting profession. For this, the chi-square test on gender versus position was carried out as shown Table 3.

Table 3

Chi-square test on Gender versus Position using 2013 base year data.

\begin{tabular}{|c|c|c|c|c|c|c|c|}
\hline \multirow{2}{*}{\multicolumn{2}{|c|}{ Description }} & & \multicolumn{3}{|l|}{ Position } & \multirow[b]{2}{*}{ Total } & \multirow[b]{2}{*}{ Sig. } \\
\hline & & & $\begin{array}{l}\text { Accounting } \\
\text { Auditor }\end{array}$ & Accountant & $\begin{array}{l}\text { Accounting } \\
\text { Assistant }\end{array}$ & & \\
\hline \multirow{4}{*}{ Gender } & \multirow{2}{*}{ Male } & Count & 2,346 & 9,471 & 3,422 & 15,239 & \multirow{4}{*}{$0.001 *$} \\
\hline & & Expected Count & $1,675.7$ & $8,259.9$ & $5,303.5$ & 15,239 & \\
\hline & \multirow{2}{*}{ Female } & Count & 1,490 & 9,438 & 8,719 & 19,647 & \\
\hline & & Expected Count & $2,160.3$ & $10,649.1$ & $6,837.5$ & 19,647 & \\
\hline
\end{tabular}

* Significance level of $5 \%$

Note: Sig. = Significance Level

Source: Research Data.

The facts show that on elite positions in the accounting profession, such as the Accounting Auditor, the expected count for males was of 1,675.7, whereas the actual count was of 2,346; on the other hand, for females the expected count was of 2,160.30 and the effective count was of 1,490 .

Regarding the position of accounting assistant, there is a high prevalence of women, corroborating Cooper (2001) on the advancement of women in the accounting profession, particularly at low levels. The advance shows that the movements of radical feminism that occurred in the mid-1960s, mainly in the UK and Australia, were not in vain; however, the evidence still denotes inequality in the upper levels of the hierarchy in the accounting profession. The results indicate that the rejection of female accession to the post of accounting auditor persists, reinforcing the findings of Gould (1983), Fisher (1987), and Cooper (2010).

In this view, women are occupying operational positions that do not require criticality in decisions. This inference seems to suggest that the assumption that women would not have the same capacity as men in the accounting profession continue to this day, as suggested by Cooper (2010). It is also corroborated by the findings of Dwyer and Roberts (2004) and Madero Gómez (2010) that domesticity prevents equal participation of women in the accounting profession and business environment. This fact confirms that gender inequality is not isolated in the accounting profession, but is widespread throughout the business environment (Madero Gómez, 2010).

The results suggest that in the accounting profession, the glass ceiling effect is disseminated on the issue of hierarchy in certain positions of accounting, corroborating the theoretical positioning of Frankforter (1996), and in relation to the occupations of women in the accounting profession, confirming the positioning of Fernandez (1998). The results corroborate the findings of Morrison and Glinow (1990) on the existence of glass ceiling that prevents women from taking leadership positions and visibility, namely those of Accounting Auditor and Accountant.

Therefore, women tend to assume positions of lower visibility, as Accounting Assistant, indicating the occurrence of glass ceiling in the accounting profession in Southern Brazil. The position of Accounting Assistant does not have supervisory functions and authority, confirming the explanations of Marsden, Kalleberg and Cook (1993) that men take on more positions of 
authority and of supervision functions. The findings allow us to infer that men sometimes do not share the functions of power and professional status, maintaining the permeability of glass ceiling in the accounting profession (Steil, 1997).

The results corroborate the concept of Pillsbury et al., (1989), that female accountants suffer a lack of growth in the profession, and that of Trapp, Hermanson and Turner (1989) on the highest ascension of male accounting professionals. Evidence indicates that the accounting profession has an invisible barrier to women concerning jobs and occupations that offer a higher income. This barrier affects women due to gender, not by the inability to occupy the Accountant and Accounting Auditor positions, since training in Accounting accredits professionals for the exercise of all these functions (Powell and Butterfield, 1994; Ohlott et al., 1994).

According to Lehman (1992), the restriction practices of women to certain positions endured World War II (Zimmeck, 1984), and the results indicate that to this day such discrimination continues.

Table 4 describes the chi-square test on Gender versus Education.

Table 4

Chi-square test on Gender versus Education using 2013 base year data.

\begin{tabular}{|c|c|c|c|c|c|c|c|}
\hline \multirow{2}{*}{\multicolumn{2}{|c|}{ Description }} & & \multicolumn{3}{|l|}{ Education } & \multirow{2}{*}{ Total } & \multirow{2}{*}{ Sig. } \\
\hline & & & College Degree & Master Degree & Doctorate & & \\
\hline \multirow{4}{*}{ Gender } & Male & Count & 15,073 & 138 & 28 & 15,239 & \multirow{4}{*}{$0.047 *$} \\
\hline & Male & Expected Count & $15,093.5$ & 117.9 & 27.5 & 15,239 & \\
\hline & \multirow{2}{*}{ Female } & Count & 19,480 & 132 & 35 & 19,647 & \\
\hline & & Expected Count & $19,459.5$ & 152.1 & 35.5 & 19,647 & \\
\hline
\end{tabular}

* Significance level of $5 \%$

Note: Sig. = Significance Level

Source: Research Data.

The results indicate that for College degree there is a close consistency between male and female. The same applies at the Doctorate level, because there is a similarity in the relation to gender; however, there was a predominance of women. The most relevant difference was in relation at the Master degree level, where males exceeded the expected count and the number of females was inferior in this count.

Generally, there is a higher ratio of women seeking professional qualification and even so they still occupy a smaller number of higher hierarchies in the accounting profession. This is contrary to the findings of Roberts and Coutts (1992), who say that women who reach adequate levels of qualifications tend to achieve higher levels of employment in the profession, and to Runyan et al. (2006), who mentions that education decreases gender inequality significantly in the business environment.

On the other hand, the findings corroborate Crompton and Sanderson (1990), who say that the increase in the academic qualification level of women does not guarantee occupying high level positions in the hierarchy of the accounting profession. The results prove the inference of Brighenti et al., (2015), in which the level of education could justify gender inequality in the accounting profession; however, this is not what happens, because women with education levels compatible with men are discriminated in their functions.

Evidence of Casa Nova (2012) on the spread of higher education and highly qualified women in a widespread scope are confirmed, and over time this factor may help the gender equality that is sorely required by both women and minorities. 
Table 5 describes the chi-square test on Gender versus Age.

Table 5

Chi-square test on Gender versus Age using 2013 base year data.

\begin{tabular}{|c|c|c|c|c|c|c|c|c|c|c|}
\hline \multirow{2}{*}{\multicolumn{2}{|c|}{ Description }} & & \multicolumn{6}{|l|}{ Age } & \multirow{2}{*}{ Total } & \multirow{2}{*}{ Sig. } \\
\hline & & & $16-20$ & $21-25$ & $26-30$ & $31-40$ & $41-50$ & $>50$ & & \\
\hline \multirow{4}{*}{ Gender } & & Count & 40 & 1,296 & 2,886 & 5,208 & 3,460 & 2,349 & 15,239 & \multirow{4}{*}{$0.001 *$} \\
\hline & Male & $\begin{array}{l}\text { Expected } \\
\text { Count }<0\}\end{array}$ & 41.9 & $1,665.6$ & $3,491.5$ & $5,579.1$ & $2,978.3$ & $1,482.6$ & 15,239 & \\
\hline & \multirow[b]{2}{*}{ Female } & Count & 56 & 2517 & 5,107 & 7,564 & 3,358 & 1,045 & 19,647 & \\
\hline & & $\begin{array}{l}\text { Expected } \\
\text { Count }\end{array}$ & 54.1 & $2,147.4$ & $4,501.5$ & $7,192.9$ & $3,839.7$ & $1,911.4$ & 19,647 & \\
\hline
\end{tabular}

* Significance level of $5 \%$

Note: Sig. = Significance Level

Source: Research Data.

The fact that younger women predominate in the accounting profession offers support to the findings of Crompton and Sanderson (1990), where the age distribution of younger women in the profession may cause implications in position and occupation, and women are represented in greater numbers at the lower levels of the accounting profession hierarchy.

Moreover, the evidence of Konstanz and Ferris (1981) is confirmed, in which women over time have greater organizational and staff turnover rates, making older men have higher growth in the professional level.

The approach by Roberts and Coutts (1992) is confirmed, since the career breaks of women aged 25 to 35 are affected over the perspectives for career advancement. Finally, the findings contradict the inferences of Barcelona et al. (1975) and of Cisneros (2015), which state that the age of women would not be a factor for discrimination; however, the inferred results were in many different periods.

We must consider that the findings on the age group may offer evidence of possible impacts on other results, since women have recently gained ground in the profession and consequently younger women are prevalent in the profession, and that such professionals need time to achieve the best career levels. Thus, future studies would be necessary for a longitudinal way to compare whether or not this attitude tends to endure, and if there are continuing invisible barriers on remuneration, or office, among other discriminatory factors arising from gender.

Table 6 shows the chi-square test on Gender versus Remuneration.

Table 6

Chi-square test on Gender versus Remuneration using 2013 base year data.

\begin{tabular}{|c|c|c|c|c|c|c|c|c|}
\hline \multirow{2}{*}{\multicolumn{2}{|c|}{ Description }} & & \multicolumn{4}{|c|}{ Remuneration } & \multirow[b]{2}{*}{ Total } & \multirow[b]{2}{*}{ Sig. } \\
\hline & & & $\begin{array}{l}<\mathrm{R} \$ \\
2,000.00\end{array}$ & $\begin{array}{l}\mathrm{R} \$ 2,000.00- \\
\mathrm{R} \$ 5,000.00\end{array}$ & $\begin{array}{l}\mathrm{R} \$ 5,000.00- \\
\mathrm{R} \$ 8,000.00\end{array}$ & $\begin{array}{l}>\mathrm{R} \$ \\
8,000.00\end{array}$ & & \\
\hline \multirow{4}{*}{ Gender } & \multirow{2}{*}{ Male } & Count & 3,725 & 6,571 & 2,521 & 2,422 & 15,239 & \multirow{4}{*}{$0.001 *$} \\
\hline & & Expected Count & $5,143.6$ & $6,698.2$ & $1,874.8$ & $1,522.3$ & 15,239 & \\
\hline & \multirow{2}{*}{ Female } & Count & 8,050 & 8,763 & 1,771 & 1,063 & 19,647 & \\
\hline & & Expected Count & $6,631.4$ & $8,635.8$ & $2,417.2$ & $1,962.7$ & 19,647 & \\
\hline
\end{tabular}

\footnotetext{
* Significance level of $5 \%$

Note: Sig. $=$ Significance Level

Source: Research Data.
} 
The results indicate that in the accounting profession, men predominantly receive higher remunerations ( $\mathrm{R} \$ 5,000.00$ to $\mathrm{R} \$ 8,000.00$ and $>\mathrm{R} \$ 8,000.00)$, whereas lower salaries $(<\mathrm{R} \$$ $2,000.00$ and $\mathrm{R} \$ 2,000,00 \mathrm{R} \$ 5,000.00)$ predominate among women.

The findings agree with Steil (1997), Bach (2014) and Brighenti et al. (2015), demonstrating lower pays for women who exercise the same professional assignments as men. The gender gap in pay remains significant, although women have obtained a similar education. The evidence of Martin (1990), Richardson (1996) and Crankshaft and Bridges (2007), along with the theoretical positioning glass ceiling outlined by Duleep and Sanders (1992) with respect to the wage differences between men and women, are confirmed. Table 7 describes the chi-square test on Gender versus Company size.

Table 7

Chi-square test on Gender versus Company Size using 2013 base year data.

\begin{tabular}{|c|c|c|c|c|c|c|c|}
\hline \multirow{2}{*}{\multicolumn{2}{|c|}{ Description }} & & \multicolumn{3}{|c|}{ Company Size } & \multirow{2}{*}{ Total } & \multirow{2}{*}{ Sig. } \\
\hline & & & Small & Medium & Large & & \\
\hline \multirow{4}{*}{ Gender } & \multirow{2}{*}{ Male } & Count & 4,057 & 3,439 & 7,743 & 15,239 & \multirow{4}{*}{$0.001 *$} \\
\hline & & Expected Count & $4,706.8$ & $3,729.6$ & $6,802.6$ & 15,239 & \\
\hline & \multirow{2}{*}{ Female } & Count & 6,718 & 5,099 & 7,830 & 19,647 & \\
\hline & & Expected Count & $6,068.2$ & $4,808.4$ & $8,770.4$ & 19,647 & \\
\hline
\end{tabular}

* Significance level of $5 \%$

Note: Sig. = Significance Level

Source: Research Data.

It can be observed in Table 7 that there is a male predominance in undertaking activities involving the accounting profession in large companies because, as noted, the expected count for men was lower than the actual number. There is a predominance of women taking positions in the accounting profession in small and medium-sized enterprises, since, as noted, the expected count for women was lower than the actual number, contradicting Brighenti et al. (2015) who states that the size of a company does not cause interference in gender inequality. Table 8 describes the chi-square test on Gender versus Time in position.

Table 8

Chi-square test on Gender versus Time in Position using 2013 base year data.

\begin{tabular}{|c|c|c|c|c|c|c|c|c|}
\hline \multirow{2}{*}{\multicolumn{2}{|c|}{ Description }} & & \multicolumn{4}{|c|}{ Time in Office } & \multirow{2}{*}{ Total } & \multirow{2}{*}{ Sig. } \\
\hline & & & $<1$ year & 1-3 years & 3-5 years & $>5$ years & & \\
\hline \multirow{4}{*}{ Gender } & \multirow{2}{*}{ Male } & Count & 3,860 & 3,874 & 2,139 & 5,366 & 15,239 & \multirow{4}{*}{$0.001 *$} \\
\hline & & Expected Count & $4,270.8$ & $4,193.9$ & $2,265.4$ & $4,508.9$ & 15,239 & \\
\hline & \multirow{2}{*}{ Female } & Count & 5,917 & 5,727 & 3,047 & 4,956 & 19,647 & \\
\hline & & Expected Count & $5,506.2$ & $5,407.1$ & $2,920.6$ & $5,813.1$ & 19,647 & \\
\hline
\end{tabular}

* Significance level of $5 \%$

Note: Sig. = Significance Level

Source: Research Data.

The results show that men in the accounting profession remain in office for longer periods of time, that is, for over five years. On the other hand, women predominate in their respective 
position in all other periods of less than five years. These results indicate that men tend to stay longer in their position in the accounting profession, which can be driven by the noninterference of caring for a family. On the other hand, women often have to give up their profession for a period of time to take care of their family, confirming the affirmations of Richardson (1996).

These findings are corroborated by Cooper Jackson (2001). According to these findings, women who have high positions are characterized by having a late marriage and few children. For Melamed (1995), the accomplishments of women were obtained mainly due to lack of domestic responsibilities. In contrast, the evidence provided by Brighenti et al. (2015) on the low interference of employment time in gender inequality is contradicted. Table 9 describes the chi-square test on Gender versus the State.

Table 9

Chi-square test on Gender versus the State using 2013 base year data.

\begin{tabular}{|c|c|c|c|c|c|c|c|}
\hline \multirow{2}{*}{\multicolumn{2}{|c|}{ Description }} & & \multicolumn{3}{|l|}{ State } & \multirow{2}{*}{ Total } & \multirow{2}{*}{ Sig. } \\
\hline & & & $\mathrm{SC}$ & $\mathrm{RS}$ & PR & & \\
\hline \multirow{4}{*}{ Gender } & \multirow{2}{*}{ Male } & Count & 4,511 & 4,157 & 6,571 & 15,239 & \multirow{4}{*}{$0.001 *$} \\
\hline & & Expected Count & $4,654.8$ & $4,637.7$ & $5,946.5$ & 15,239 & \\
\hline & \multirow{2}{*}{ Female } & Count & 6,145 & 6,460 & 7,042 & 19,647 & \\
\hline & & Expected Count & $6,001.2$ & $5,979.3$ & $7,666.5$ & 19,647 & \\
\hline
\end{tabular}

* Significance level of $5 \%$

Note: Sig. $=$ Significance Level

Source: Research Data.

The results indicate that women predominate in the accounting profession with a greater ratio in the states of Santa Catarina and Rio Grande do Sul, whereas men have a higher prevalence in Paraná.

\section{Analysis of homogeneity among variables}

Subsequently, the application of the correspondence analysis (HOMALS) was carried out, showing the total variance explained by each dimension. Thus, it was observed that the two dimensions explain $30.4 \%$ and $16.6 \%$ of the data variation, respectively. Table 10 shows the discrimination measures informing on the most important variables in each dimension.

Table 10

Discrimination measures using 2013 base year data.

\begin{tabular}{lll}
\hline Variable & Dimension & \\
\cline { 2 - 3 } & 1 & 2 \\
\hline Position & 0,448 & 0,202 \\
Education & 0,005 & 0,004 \\
Age & 0,380 & 0,424 \\
Remuneration & 0,689 & 0,447 \\
Gender & 0,172 & 0,074 \\
Company Size & 0,323 & 0,033 \\
Time in Position & 0,400 & 0,122 \\
State & 0,012 & 0,021 \\
\hline
\end{tabular}

Source: Research Data. 
The result is consistent with the glass ceiling approach in which the variables of gender, position, compensation, company size, and time in the position are factors that can determine barriers that prevent women from joining the most prestigious careers and achieve remuneration consistent with that of men. The graphical representation of the discrimination measures is shown in Figure 1, as follows.

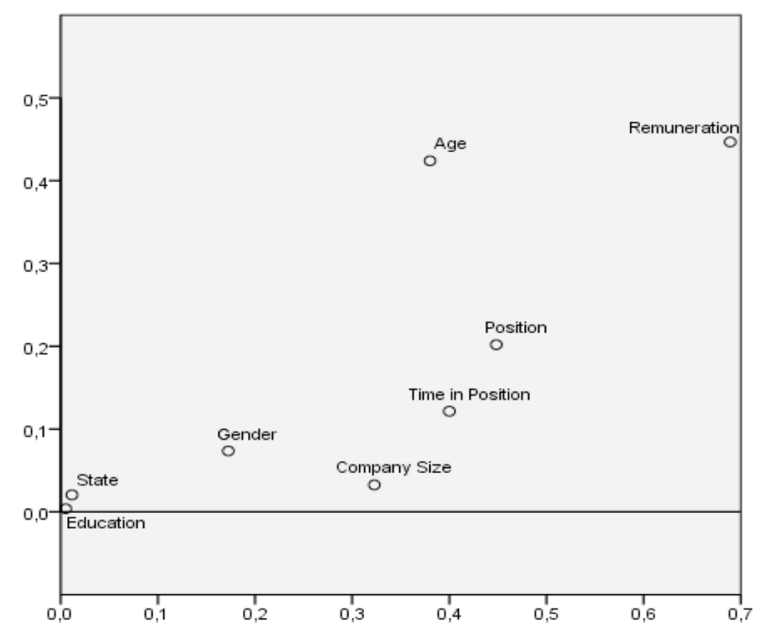

Figure 1

Discrimination measures using 2013 base year data.

Source: Research Data.

From figure 1, it can be inferred that the main variables that discriminate the studied group are position, time in position, company size, gender, age, and remuneration. Finally, the correspondence relationships among variable categories are presented, and Figure 2 shows the correspondence distribution of the research categories.

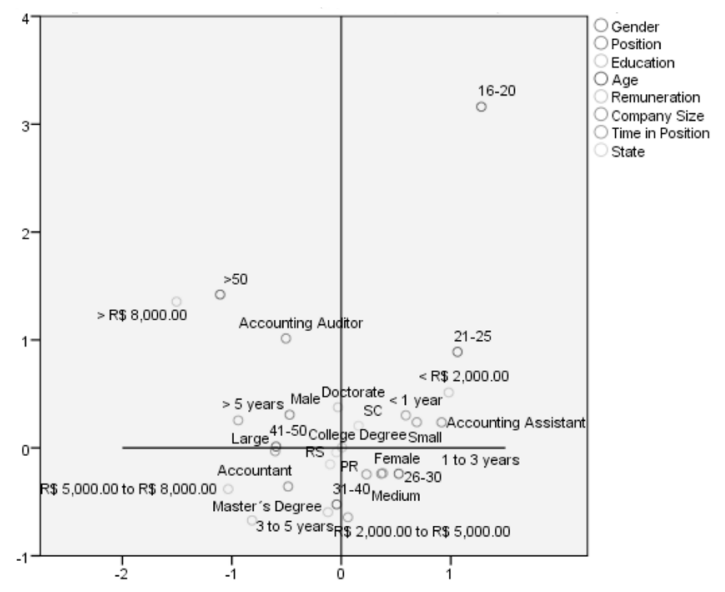

Figure 2

Correspondence distribution of the categories using 2013 base year data.

Source: Research Data. 
The results indicate that the female accounting professional is closer to small and mediumsized businesses, a shorter time in the company ( 1 to 3 years), age between 26 and 30 years, in the states of Santa Catarina and Rio Grande do Sul, the position of Accounting Assistant, and are paid less than $\mathrm{R} \$ 2,000.00$ per month. However, the male accounting professional is closer to a higher salary (over R $\$ 8,000.00$ ), a position of Accounting Auditor, a 50-year-old age, and a long experience in the position (over five years). The above evidence confirms the findings in the chi-square test.

\section{Conclusions}

In the context of the observed universe-namely, workers with formal employment links in accounting in 2013 - it was possible to answer the question to the research problem, noting that inequality with regard to gender is part of the daily life of the Accounting professionals. Moreover, the results indicate that in the accounting profession, in most cases, the facts are not controversial findings of other professional areas highlighted in the review of literature, because the occurrence of gender inequalities and the glass ceiling effect were found in the accounting profession. The results show that the highest positions in the accounting profession-Accounting and Accountant Auditor-are occupied mainly by male professionals. This is confirmed when the significant differences between the performance of men and women are observed, according to which the operational function and lower hierarchy, namely the Accounting Assistant, has a predominance of females.

With regard to education, - although there is statistical significance of $10 \%$ for the occurrence of differences between the expected and the actual values - the results indicate a better symmetry between the level of education for gender, a fact that disqualifies the assumption that education could justify wage and occupation differences in management positions between gender. Moreover, the results show that among younger professionals, there is a predominance of women.

The results suggest that the entry difficulties of women into the accounting profession also persist in Brazil, reflecting the findings of Lehman (1992), Runyan et al. (2006), Madero Gómez (2010), Bach (2014), and Cisneros (2015). It was also observed that men in the accounting profession tend to get higher pay remuneration than women. Furthermore, the results show that there is a predominance of men taking accounting profession activities in large businesses, while women perform such activities in small and medium size businesses. Also, in most cases, men stay in accounting positions in the same company for longer periods of time in relation to women.

Furthermore, it is stated that female professionals correspond more closely to the small and medium-sized businesses, to shorter work times, to lower age ranges, to the position of Accounting Assistant-although they have a similar educational level-and to lower remuneration. On the other hand, male professionals correspond more closely to higher salaries, a longer stay in the company, and activities in large businesses.

The results may indicate an expansion of the accounting profession, and as if to address the gender inequality, the number of women in the profession has increased. The inference of Roberts and Coutts (1992) is reflected in the need for a qualified labor force, which caused an expansion in the number of job vacancies for women in the accounting profession.

Therefore, it is noted that the survey results show that the accounting profession is also 
the influence for the glass ceiling corroborating studies of Richardson (1996), Barker and Monks (1998), Twomey et al. (2002), Haynes (2008), Abidin et al. (2009) and Bruce-Twum (2013), which were carried out at the international level. The results show that the highest activities in the accounting profession, such as those of the Accounting Auditor, and those of the professional hierarchy command, as those of the Accountant, are in most cases performed by male accounting professionals. Observing that the operational and lower positions in the hierarchy, such as Accounting Assistant, are usually performed by professionals of both genders, confirms the stated facts.

Another highlight in the influence of glass ceiling in the accounting profession is the ratio of education between genders. In view of this, it is not surprising that even in the face of equivalent training, women in the accounting profession tend to predominantly work in lower positions than men. That is, the disclosure is diagnosed by the effects since the imposed barrier is invisible in the organizations.

Based on empirical evidence, it is essential to break the invisible barrier that prevents women from achieving higher positions within organizations, whether private or governmental. Thus, the contribution of this study on the accounting profession is worth noting.

The scarcity of women at the highest levels of the accounting profession is a silent recognition of the very existence of glass ceiling against women in the profession, and a reflection of their subordinate position in society. It is concluded that the pursuit of gender equality has advanced, but there is still much to go in the accounting profession to dismantle patriarchal structures and minimize the effect of glass ceiling, supporting the rhetoric of post-feminism exposed by Kelan (2008).

Based on the studies by Powell, Baglioli and Dainty (2009), Michelson (2009), England (2010), Adams (2010), Crompton and Lyonette (2011) and Walsh (2012), it is generally inferred that gender inequality persists in the rise of women to the professional world and that this is not a reality particular to the accounting profession, but rather that it corroborates other professional realities, even those in the health field which historically has provided greater incentives for the rise of women.

It is noteworthy that in the glass ceiling approach, the criteria established by Cotter et al. (2001) was used partially to emphasize the influence of the accounting profession, where gender inequality was explained by compensation, age, occupation and professional hierarchy characteristics, and where inequality is greater at higher levels of the accounting hierarchy. The criteria that have not been met were the verification of the increase in inequality throughout a career and the chances of career advancement. In order to conduct empirical research focusing on the criteria not met, the expansion of different methods and qualitative research and/or case studies with direct observations are necessary, enabling advances in the glass ceiling research in the accounting profession, particularly in audit firms.

The limitation of this study is the information provided by the RAIS, the delimitation to a single region of the country, and the transversal cut. Therefore, future studies following this line of research could increase the number of geographic regions and adopt a longitudinal cut, which may or may not identify the occurrence of changes through time. 
http://dx.doi.org/10.22201/fca.24488410e.2018.928

\section{References}

Abidin, Z. Z., Rashid, A. A., and Jusoff, K. (2009). The 'Glass Ceiling' Phenomenon for Malaysian Women Accountants. Asian Culture and History, 1 (1): 38. https://doi.org/10.5539/ach.v1n1p38

Acs, Z., Bardasi, E., Estrin, S. and Svejnar, J. (2011). Introduction to special issue of small business economics on female entrepreneurship in developed and developing economies. Small Business Economics, 37 (4): $393-396$. https://doi.org/10.1007/s11187-011-9372-1

Adams, T. L. (2010). Gender and feminization in health care professions. Sociology compass, 4(7), 454-465. https://doi.org/10.1111/j.1751-9020.2010.00294.x

Attie, W. (2006). Auditoria: Conceitos e Aplicações 3. ed. São Paulo: Atlas.

Bach, S. (2014). Frauen erzielen im Durchschnitt nur halb so hohe Einkommen wie Männer. DIW-Wochenbericht, 81 (35): 803-813.

Barcelona, C., Lelievre, T., and Lelievre, C. (1975). Women in accounting: eddies and midstream currents. The Woman CPA, 35: 3-5.

Barker, P. C., and Monks, K. (1998). Irish women accountants and career progression: a research note. Accounting, Organizations and Society, 23 (8): 813-823. https://doi.org/10.1016/s0361-3682(98)00009-9

Brasil, Resolução CFC n. ${ }^{\circ}$ 560, de 28 de outubro de 1983. Dispõe sobre as Prerrogativas Profissionais. Regulamentação da Profissão de Contador. [Consulted 27 apr 2017]. Available in: $<$ http://www.cosif.com.br $>$.

Brighenti, J., Jacomossi, F., and Silva, M. Z. D. (2015). Desigualdades de gênero na atuação de contadores e auditores no mercado de trabalho catarinense. Enfoque: Reflexão Contábil, 34 (2): 109-122. https://doi.org/10.4025/ enfoque.v34i2.27807

Bruce-Twum, E. (2013). The Accounting Profession and the Female Gender in Ghana. Accounting and Finance Research, 2 (1): 54-60. https://doi.org/10.5430/afr.v2n1p54

Bruschini, M. C. A. (2007). Trabalho e gênero no Brasil nos últimos dez anos. Cadernos de Pesquisa, 37 (132): $537-$ 572. https://doi.org/10.1590/s0100-15742007000300003

Cambota, J. N., and Pontes, P. A. (2007). Desigualdade de rendimentos por gênero intra-ocupações no Brasil, em 2004. Revista de Economia Contemporânea, Rio de Janeiro, 11 (2): 331-350. https://doi.org/10.1590/s141598482007000200006

Casa Nova, S. P. D. C. (2012). Impactos de Mestrados Especiais em Contabilidade na trajetória de seus egressos: um olhar especial para gênero. Revista Contabilidade e Controladoria, 4 (3): 37-62.

Cavazotte, F. S. C. N., de Oliveira, L. B., and de Miranda, L. C. (2010). Desigualdade de gênero no trabalho: reflexos nas atitudes das mulheres e em sua intenção de deixar a empresa. Revista de Administração, 45 (1): 70-83. https:// doi.org/10.1016/s0080-2107(16)30510-6

Ciancanelli, P., Gallhofer, S., Humphrey, C., and Kirkham, L. (1990). Gender and accountancy: some evidence from the UK. Critical Perspectives on Accounting, 1 (2): 117-144. https://doi.org/10.1016/1045-2354(90)02011-7

Cisneros, M. E. E. (2015). Desempeño de nuevos negocios: perspectiva de género. Contaduría y Administración, 60 (2): 468-485. https://doi.org/10.1016/s0186-1042(15)30010-3

Cooper Jackson. J. (2001). Women middle managers' perception of the glass ceiling. Women in Management Review, 16 (1): 30-41. https://doi.org/10.1108/09649420110380265

Cooper, C. (2001). From women's liberation to feminism: reflections in accounting academia. Accounting Forum, 25 (3): 214-245 https://doi.org/10.1111/1467-6303.00064

Cooper, K. (2010). Accounting by women: Fear, favour and the path to professional recognition for Australian women accountants. Accounting History, 15 (3): 309-336. https://doi.org/10.1177/1032373210368422

Cotter, D. A., Hermsen, J. M., Ovadia, S., and Vanneman, R. (2001). The glass ceiling effect. Social forces, 80 (2): 655-681.

Crompton, R., and Sanderson, K. (1990). Gendered jobs and social change. Routledge.

Crompton, R., and Lyonette, C. (2011). Women's career success and work-life adaptations in the accountancy and medical professions in Britain. Gender, Work \& Organization, 18(2), 231-254. https://doi.org/10.1111/j.14680432.2009.00511.x 
Cullen, L., and Christopher, T. (2012). Career Progression of Female Accountants in the State Public Sector. Australian Accounting Review, 22 (1): 68-85. https://doi.org/10.1111/j.1835-2561.2011.00159.x

Da Silva, B. A. C., de Oliveira Carrara, E., da Cruz Alves, F., da Silva, I. C., Junior, M. L. P., and Moraes, M. R. (2011). Profissão Contábil: estudo das características e sua evolução no brasil. [Consulted 12 feb 2017]. Available in: http://www.manoel.pro.br/ProfissaoContabil-I-3e4.pdf.

Duleep, H. O., and Sanders, S. (1992). Discrimination at the Top: American-Born Asian and White Men. Industrial Relations: A Journal of Economy and Society, 31 (3): 416-432. https://doi.org/10.1111/j.1468-232x.1992.tb00318.x

Dwyer, P. D., and Roberts, R. W. (2004). The contemporary gender agenda of the US public accounting profession: embracing feminism or maintaining empire?. Critical Perspectives on Accounting, 15 (1): 159-177. https://doi. org/10.1016/s1045-2354(03)00003-0

Dwyer, P., Johnston, M., and Miller, K. L. (1996). Europe's corporate women. Business Week, 15: 40-2.

Eagly, A. H., Johannesen-Schmidt, M. C., and Van Engen, M. L. (2003). Transformational, transactional, and laissez-faire leadership styles: a meta-analysis comparing women and men. Psychological Bulletin, 129 (4): $569-91$. https://doi.org/10.1037/0033-2909.129.4.569

England, P. (2010). The gender revolution uneven and stalled. Gender \& Society, 24(2), 149-166.

Federal Glass Ceiling Commission. (1995). Glass Ceiling Commission - Good for Business: Making Full Use of the Nation's Human Capital. [Consulted 14 aug 2017]. Available in: <http://digitalcommons.ilr.cornell.edu/key_workplace>.

Fernandez, M. (1998). Asian Indian Americans in the Bay Area and the glass ceiling. Sociological Perspectives, 41 (1): 119-149. https://doi.org/10.2307/1389356

Fisher, A. B. (1987). Where women are succeeding. Fortune, 116 (3): 78.

Franco, H., and Marra, E. (2001). Auditoria Contábil: Normas de Auditoria; Procedimentos e papéis de trabalho; Programas de Auditoria; Relatórios de Auditoria 4. ed. São Paulo: Atlas.

Frankforter, S. A. (1996). The progression of women beyond the glass ceiling. Journal of Social Behavior and Personality, 11 (5): 121-132.

Gould, C. (1983). One Percent of the Big Eight. Working Woman, 160-163.

Haynes, K. (2008). Moving the gender agenda or stirring chicken's entrails? Where next for feminist methodologies in accounting? Accounting, Auditing \& Accountability Journal, 21 (4): 539-555. https://doi. org/10.1108/09513570810872914

Hoffmann, G. H. (2004). Responsabilidade social e a questão de gênero. Revista Fae Business, 9: 22-23. Instituto Brasileiro de Geografia e Estatística (IBGE). (2014). Estadosat. [Consulted 14 aug 2017]. Available in: $<$ http://www.ibge.gov.br/estadosat/>.

Kelan, E. K. (2008). The discursive construction of gender in contemporary management literature. Journal of Business Ethics, 81 (2): 427-445. https://doi.org/10.1007/s10551-007-9505-2

Konstans, C., and Ferris, K. (1981). Female turnover in professional accounting firms: Some preliminary findings. The Michigan CPA, 32 (4): 20-24.

Lehman, C. R. (1992). "Herstory" in accounting: The first eighty years.Accounting, Organizations and Society, 17 (3): 261-285. https://doi.org/10.1016/0361-3682(92)90024-m

Lopes, A. B. (2002). A Informação Contábil e o Mercado de Capitais. São Paulo: Pioneira Thomson Learning.

Lupu, I. (2012). Approved routes and alternative paths: The construction of women's careers in large accounting firms. Evidence from the French Big Four. Critical Perspectives on Accounting, 23 (4): 351-369. https://doi.org/10.1016/j.cpa.2012.01.003

Madero Gómez, S. M. (2010). Factores relevantes del desarrollo profesional y de compensaciones en la carrera laboral del trabajador. Contaduría y administración, (232): 109-130.

Marsden, P. V., Kalleberg, A. L., and Cook, C. R. (1993). Gender differences in organizational commitment influences of work positions and family roles. Work and Occupations, 20 (3): 368-390. https://doi. org/10.1177/0730888493020003005

Martin, J. (1990). Deconstructing organizacional taboos: the supression of gender conflict in organizations. Organization Science, 1 (4): 339-359. https://doi.org/10.1287/orsc.1.4.339

Melamed, T. (1995). Career success: The moderating effect of gender. Journal of Vocational Behavior, 47 (1), 35-60. https://doi.org/10.1006/jvbe.1995.1028 
Meyerson, D. E., and Fletcher, J. K. (2000). A modest manifesto for shattering the glass ceiling. Harvard Business Review, 78 (1): 126-136.

Michelson, E. (2009). Gender inequality in the Chinese legal profession. Research in the Sociology of Work, 19, $337-376$. Morrison, A., and Glinow, M. (1990). Womem and minorities in management. American Psychologist, 45 (2), $200-208$.

Muzio, D., and Tomlinson, J. (2012). Editorial: researching gender, inclusion and diversity in contemporary professions and professional organizations. Gender, Work \& Organization, 19(5), 455-466. https://doi.org/10.1111/ j.1468-0432.2012.00608.x

Oakley, J. G. (2000). Gender-based barriers to senior management positions: understanding the scarcity of female CEOs. Journal of Business Ethics, 27 (2): 321-35.

Ohlott, P. J., Ruderman, M. N., and McCauley, C. D. (1994). Gender differences in managers' developmental job experiences. Academy of Management Journal, 37 (1): 46-67. https://doi.org/10.2307/256769

Pear, R. (1987). Women reduce lag in earnings but disparities with men remain. New York Times (September 4).

Pillsbury, C., Capozzoli, L., and Ciampa, A. (1989). A Synthesis of research studies regarding the upward mobility of women in public accounting, Accounting Horizons, 63-70.

Powell, G., and Butterfield, D. A. (1994). Investigating the glass-ceiling phenomenon: an empirical study of factual promotion to top management. Academy of Management Journal, 37 (1): 68-86. https://doi.org/10.2307/256770

Powell, A., Bagilhole, B., and Dainty, A. (2009). How women engineers do and undo gender: consequences for gender equality. Gender, Work \& Organization, 16(4), 411-428. https://doi.org/10.1111/j.1468-0432.2008.00406.x

Relatório Anual de Informações Sociais - RAIS. (2013). Available in: http://portal.mte.gov.br/: Consulted 19 Jan 2016.

Ricardino, A., and Carvalho, L. N. (2004). Breve retrospectiva do desenvolvimento das atividades de auditoria no Brasil. Revista Contabilidade \& Finanças, 15(35), 22-34. https://doi.org/10.1590/s 1519-70772004000200002

Richardson, C. (1996). Snakes and ladders? The differing career patterns of male and female accountants. Women in Management Review, 11 (4): 13-19. https://doi.org/10.1108/09649429610122104

Ridgeway, C. L. (2001). Sex, status, and leadership. Journal of Social Issues, 57 (4): 637-55.

Roberts, J., and Coutts, J. A. (1992). Feminization and professionalization: a review of an emerging literature on the development of accounting in the United Kingdom. Accounting, Organizations and Society, 17 (3), $379-395$. https://doi.org/10.1016/0361-3682(92)90030-v

Rothwell, S. (1985). Is management a masculine role? Management Education and Development, 16 (2): $79-98$. https://doi.org/10.1177/135050768501600202

Runyan, R. C., Huddleston, P., and Swinney, J. (2006). Entrepreneurial orientation and social capital as small firm strategies: A study of gender differences from a resource-based view. The International Entrepreneurship and Management Journal, 2 (4): 455-477. https://doi.org/10.1007/s11365-006-0010-3

Steil, A. V. (1997). Organizações, gênero e posição hierárquica-compreendendo o fenômeno do teto de vidro. Revista de Administração da Universidade de São Paulo, 32 (3): 62-69.

Stelter, N. Z. (2002). Gender differences in leadership: current social issues and future organizational implications. Journal of Leadership Studies, 8 (4): 88-100. https://doi.org/10.1177/107179190200800408

Trapp, M., Hermanson, R., and Turner, D. (1989). Current perceptions of issues related to women employed in public accounting. Accounting Horizons, 71-85.

Twomey, A. M., Linehan, M., and Walsh, J. S. (2002). Career progression of young female accountants: evidence from the accountancy profession in Ireland. Journal of European Industrial Training, 26 (2/3/4), 117-124. https://doi. org/10.1108/03090590210421996

Walsh, J. (2012). Not worth the sacrifice? Women's aspirations and career progression in law firms. Gender, Work \& Organization, 19(5), 508-531

Wescott, S. H., and Seiler, R. E. (1986). Women in the accounting profession. Markus Wiener Publishers. World Bank (2010). Enterprise survey. [Consulted 30 Jun 2017]. Available in: http://espanol.enterprisesurveys. org/Custom/

Wright, E. O., Baxter, J., and Birkelund, G. E. (1995). The gender gap in workplace authority: A cross-national study. American sociological review, 407-435. https://doi.org/10.2307/2096422

Zimmeck, M. (1984). Strategies and stratagems for the employment of women in the British Civil Service, 19191939. The Historical Journal, 27 (04): 901-924. https://doi.org/10.1017/s0018246x0001815x 